\title{
Correlation between second trimester beta human chorionic gonadotropin levels and pregnancy outcome in high risk group
}

\author{
Praveen Sharma*, Sunita Maheshwari, Shivani Barala
}

Department of Obstetrics and Gynaecology, RNT Medical College, Udaipur, Rajasthan, India

Received: 22 May 2016

Accepted: 11 June 2016

\section{*Correspondence:}

Dr. Praveen Sharma,

E-mail: praveen.sharma2k14@gmail.com

Copyright: $\odot$ the author(s), publisher and licensee Medip Academy. This is an open-access article distributed under the terms of the Creative Commons Attribution Non-Commercial License, which permits unrestricted non-commercial use, distribution, and reproduction in any medium, provided the original work is properly cited.

\section{ABSTRACT}

Background: Current obstetric practice uses second trimester maternal serum levels of alpha fetoprotein, beta human chorionic gonadotropin ( $\beta \mathrm{hCG}$ ), unconjugated estradiol as a screening tool for fetal aneuploidy. Given the obvious role of placenta in determining the maternal serum levels of these hormones, we evaluate their role as predictors of placental dysfunction as manifested by pregnancy outcome.

Methods: This prospective study was done in department of obstetrics and gynecology, RNT Medical College, Udaipur, Rajasthan on 150 patients attending the antenatal OPD and those admitted between 16 to 20 weeks of pregnancy. Mid-trimester serum $\beta$ hCG levels was obtained in these patients. They were followed up till delivery or abortion to see for development of any obstetrical complication.

Results: Out of 100 cases in study group, 17\% cases had level of serum $\beta$ hCG $>2$ MOM and $83 \%$ cases had $<2$ MOM. Out of 50 cases in control group, $8 \%$ cases had level of serum $\beta$ hCG $>2$ MOM and $92 \%$ cases had $<2$ MOM. Out of 17 cases in study group with high level of serum $\beta$ hCG, $82.35 \%$ and $0 \%$ out of 4 cases in control group, developed PIH. Out of 17 cases with high level of $\beta$ hCG in study group, 58.85\% and $25 \%$ out of 4 cases in control group, developed IUGR.

Conclusions: Women with bad obstetric history and unexplained elevation of serum $\beta$ hCG during second trimester are at an increased risk for PIH and IUGR.

Keywords: $\beta$ hCG, PIH, IUGR

\section{INTRODUCTION}

Antepartum assessment is an essential component of obstetrics. One of the important aspects of antenatal care is to identify pregnancies at risk for fetal complications. Since years, there has been a search for early predictors of high risk pregnancy so that intensive antenatal care can be given to these patients. Current obstetric practice uses second trimester maternal serum levels of alpha fetoprotein, beta human chorionic gonadotropin ( $\beta \mathrm{hCG}$ ), unconjugated estradiol as a screening tool for fetal aneuploidy. Given the obvious role of the placenta in determining the maternal serum levels of these hormones, we sought to evaluate their role as predictors of placental dysfunction as manifested by pregnancy outcome. ${ }^{1}$

$\beta$ hCG so called pregnancy hormone is a glycoprotein which is structurally related to three other glycoprotein hormones LH, FSH, TSH and has a biological activity very similar to luteinizing hormone (LH). The $\beta$ subunit of all four hormones is identical. The $\beta$ subunits are characterized by distinctly different amino acid sequences. $\beta$ hCG is produced almost exclusively in the placenta but is also synthesized in the fetal kidney. ${ }^{2}$ The specific mechanism for maternal serum $\beta$ hCG level elevation in pregnancies with adverse outcome is 
unknown, but placental immaturity (also related to growth restrictions and pre-maturity) and utero placental under perfusion leading to placental vascular changes have been suggested. Reactive hyperplasia of cytotrophoblastic cells induced by placental hypoxia secondary to hypertensive disorder is responsible for increased production of $\beta$ hCG hormone. A study on the association of the mid-trimester $\beta$ hCG levels and subsequent development of pregnancy complications and adverse pregnancy outcomes is indicated and if the association exists a mid-trimester screening programme can be developed to assess those at increased risk for developing these complications. The aim of our study was to investigate the association of $2^{\text {nd }}$ trimester $\beta$ hCG levels and the pregnancy outcome.

\section{METHODS}

This prospective study was carried out in the department of obstetrics and gynaecology, RNT medical college, Udaipur, Rajasthan, India on a minimum of 150 patients attending the antenatal OPD as well as those admitted between 16 to 20 weeks of pregnancy.

Out of 150 patients, 50 patients served as controls and 100 patients, were included in the study group. Midtrimester $\beta$ hCG serum levels was obtained in all these patients. Subsequently, all these patients were followed up till delivery or abortion to see for development of any obstetrical complications.

\section{For study group}

Woman with singleton pregnancy with gestational age between $16^{\text {th }}$ and $20^{\text {th }}$ week of pregnancy with past history of following were included;

- Pregnancy induced hypertension

- Spontaneous abortion (recurrent, missed)

- Still births

- Accidental hemorrhage

- Intrauterine growth restrictions in previous pregnancy.

\section{For control group}

Women with uncomplicated singleton pregnancies without any adverse obstetric outcome in the past were included.

A detailed history was taken as per preformat of the patients attending the antenatal OPD or registered in the indoor department followed by a complete general, physical and systemic examination.

Gestational age was calculated from the first day of last menstrual period or by ultrasound. After informed consent from the woman venous blood samples of about $2 \mathrm{ml}$ was obtained in a test tube. For detection and quantification of $\beta$ hCG sandwich type immune assay was used. This method allows the determination of $\beta$ hCG from 1 to $200,000 \mu / \mathrm{ml}$.

Range of expected values according to gestational age $\left(2^{\text {nd }}\right.$ Trimester) was 4,500 miu/ml- $1,14,400 \mathrm{miu} / \mathrm{ml}$.

The $\beta$ hCG levels were expressed as multiples of median (MOM). Multiples of median were calculated from the normal range available. Maternal serum $\beta \mathrm{hCG}$ at mid trimester was considered raised when levels were more than 2 multiples of median. A correlation was then established between the elevated levels of $\beta$ hCG during 16-20 weeks of pregnancy and the pregnancy outcome. All women were followed up to the end of pregnancy.

Data thus obtained was analysed using appropriate statistical tests.

\section{RESULTS}

Out of 100 cases in the study group there were no prim gravidas $(0 \%)$ whereas in control group, out of 50 cases, $31(62 \%)$ were prim gravida.

Out of 100 cases in the study group and 50 in control group $17(17 \%)$ cases and $4(8 \%)$ cases had high levels of hCG (>2MOM), and $83(83 \%)$ cases and $46(92 \%)$ cases had low levels of $\beta$ hCG (<2MOM) respectively. There was no significant difference in the levels of $\beta$ hCG in study and control group (Table 1).

Table 1: $\beta$ hCG levels in study and control group.

\begin{tabular}{|c|c|c|c|c|c|}
\hline \multirow{2}{*}{$\begin{array}{l}\beta \mathrm{hCG} \\
\text { levels }\end{array}$} & \multicolumn{2}{|c|}{$\begin{array}{l}\text { Study group } \\
(\mathrm{n}=\mathbf{1 0 0})\end{array}$} & \multicolumn{2}{|c|}{$\begin{array}{l}\text { Control } \\
\text { group }(n=50)\end{array}$} & \multirow{2}{*}{$\begin{array}{l}\text { p } \\
\text { value }\end{array}$} \\
\hline & $\begin{array}{l}\text { No. of } \\
\text { patients }\end{array}$ & $\%$ & $\begin{array}{l}\text { No. of } \\
\text { patients }\end{array}$ & $\%$ & \\
\hline $\begin{array}{l}>2 \mathrm{MOM} \\
\text { (high) }\end{array}$ & 17 & 17 & 4 & 8 & 0.102 \\
\hline $\begin{array}{l}\leq 2 \mathrm{MOM} \\
\text { (low) }\end{array}$ & 83 & 83 & 46 & 92 & 0.847 \\
\hline
\end{tabular}

Out of 100 cases in study group and 50 cases in control group $19(19 \%)$ cases and $5(10 \%)$ cases developed $\mathrm{PIH}$ respectively. $17(17 \%)$ and $4(8 \%)$ cases had high levels of $\beta$ hCG and $83(83 \%)$ and $46(92 \%)$ cases had low levels of $\beta$ hCG in study and control group respectively. Among the cases with high levels of $\beta$ hCG, 14 out of 17 $(82.4 \%)$ cases in study group and 0 out of $4(0 \%)$ cases in control group developed PIH. In cases with low levels of $\beta$ hCG, 5 out of $83(6 \%)$ cases in study group and 5 out of $46(10.9 \%)$ cases in control group developed PIH. It was observed that in cases with bad obstetric history and raised $\beta$ hCG levels the chances of developing PIH was statistically significant $(\mathrm{p}=<0.001)$ with a relative risk of 13.7 (5.7-32.9) 95\% CI. Raised $\beta$ hCG levels were significant in predicting PIH in high risk group (Table 2). 
Table 2: Relationship of pregnancy induced hypertension with $\beta$ hCG levels.

\begin{tabular}{|c|c|c|c|c|c|c|c|c|}
\hline \multirow{3}{*}{ Group of patients } & \multicolumn{3}{|c|}{$\beta \mathrm{hCG}^{\mathrm{a}}>2 \mathrm{MOM}^{\mathrm{b}}$} & \multicolumn{3}{|c|}{$\beta \mathrm{hCG}^{\mathrm{a}} \leq 2 \mathrm{MOM}^{\mathrm{b}}$} & \multirow{3}{*}{$\begin{array}{l}\text { Relative risk } \\
\left(95 \% \mathrm{CI}^{\mathrm{d}}\right)\end{array}$} & \multirow{3}{*}{ P value } \\
\hline & \multirow{2}{*}{ Total } & \multicolumn{2}{|c|}{$\mathbf{P I H}^{\mathrm{c}}$} & \multirow{2}{*}{ Total } & \multicolumn{2}{|c|}{$\mathbf{P I H}^{\mathrm{c}}$} & & \\
\hline & & No. & $\%$ & & No. & $\%$ & & \\
\hline $\begin{array}{l}\text { Study group patients with }(\mathrm{BOH}) \\
\text { bad obstetric history }(\mathrm{n}=100)\end{array}$ & 17 & 14 & 82.4 & 83 & 5 & 6.0 & $13.7(5.7-32.9)$ & $<0.001^{*}$ \\
\hline $\begin{array}{l}\text { Control group patients without } \\
\text { bad obstetric history }(n=50)\end{array}$ & 4 & 0 & 0.0 & 46 & 5 & 10.9 & $0.0(0.0-0.0)$ & 1.000 \\
\hline Total & 21 & 14 & 66.7 & 129 & 10 & 7.8 & $8.6(4.4-16.8)$ & $<0.001 *$ \\
\hline
\end{tabular}

$\mathrm{a}=\beta \mathrm{hCG}=$ beta human chorionic gonadotrophin, $\mathrm{b}=\mathrm{MOM}=$ multiples of median, $\mathrm{c}=\mathrm{PIH}=$ pregnancy induced hypertension, $\mathrm{d}=\mathrm{CI}=$ confidence interval, * Significant $\mathrm{P}$ value.

Out of 100 cases in study group and 50 cases in control group $28(28 \%)$ cases and $7(14 \%)$ cases developed IUGR in both group respectively. $17(17 \%)$ and $4(8 \%)$ cases had high levels of $\beta$ hCG and 83 (83\%) and 46 (92\%) cases had low levels of $\beta$ hCG in study and control group respectively. Among the cases with high levels of $\beta$ hCG, 10 out of $17(58.8 \%)$ cases in study group and 1 out of $4(25 \%)$ cases in control group developed IUGR. In cases with low levels of $\beta$ hCG, 18 out of 83 (21.7\%) cases and 6 out of $46(13 \%)$ in both groups respectively developed IUGR.
It was observed that in cases with bad obstetric history and raised $\beta$ hCG levels, the chances of developing IUGR was statistically significant $(\mathrm{p}=0.005)$ with a relative risk of $2.7(1.5-4.8) 95 \%$ CI.

It was also observed that in cases without bad obstetric history and raised $\beta$ hCG levels the chances of developing IUGR was not statistically significant $(\mathrm{p}=0.464)$ with a relative risk of $1.9(0.3-12.2) 95 \%$ CI.

Raised $\beta$ hCG levels were significant in predicting IUGR in high risk group (Table 3 ).

Table 3: Relationship of IUGRA with $\beta$ hCG levels.

\begin{tabular}{|c|c|c|c|c|c|c|c|c|}
\hline \multirow{3}{*}{ Group of patients } & \multicolumn{3}{|c|}{$\beta \mathrm{hCG}>2 \mathrm{MOM}$} & \multicolumn{3}{|c|}{$\beta \mathrm{hCG} \leq 2 \mathrm{MOM}$} & \multirow{3}{*}{$\begin{array}{l}\text { Relative risk } \\
(95 \% \mathrm{CI})\end{array}$} & \multirow{3}{*}{ P value } \\
\hline & \multirow{2}{*}{ Total } & \multicolumn{2}{|c|}{$\mathbf{I U G R}^{\mathrm{a}}$} & \multirow{2}{*}{ Total } & \multicolumn{2}{|c|}{ IUGR $^{\mathbf{a}}$} & & \\
\hline & & No. & $\%$ & & No. & $\%$ & & \\
\hline $\begin{array}{l}\text { Study group patients with }(\mathrm{BOH}) \text { bad } \\
\text { obstetric history }(n=100)\end{array}$ & 17 & 10 & 58.8 & 83 & 18 & 21.7 & $2.7(1.5-4.8)$ & $0.005^{*}$ \\
\hline $\begin{array}{l}\text { Control group patients without bad } \\
\text { obstetric history }(n=50)\end{array}$ & 4 & 1 & 25.0 & 46 & 6 & 13.0 & $1.9(0.3-12.2)$ & 0.464 \\
\hline Total & 21 & 11 & 52.4 & 129 & 24 & 18.6 & $2.8(1.6-4.9)$ & 0.002 \\
\hline
\end{tabular}

$\mathrm{a}=\mathrm{IUGR}=$ intra uterine growth restriction $*$ Significant $\mathrm{P}$ value.

\section{DISCUSSION}

Out of 150 cases, 100 cases were included in the study group and 50 cases were included in the control group. Study group included patients with previous bad obstetric history. Control group included patients without previous bad obstetric history. Mid-trimester serum $\beta$ hCG levels were obtained in all these patients. Subsequently, all these patients were followed up till delivery or abortion to see for development of any obstetrical complications. In the present study all the cases in the study group were multigravida whereas in control group $62 \%$ were prim gravida and $38 \%$ were multigravida. In the study of Valliant p et al $44.2 \%$ were prim gravida and $55.5 \%$ were multigravida. The study of Valliant $\mathrm{P}$ et al was a random retrospective study and our study was a prospective study hence there were the differences in the incidence of prim gravida and multigravida. ${ }^{3}$

In the present study group, cases who developed any complications, $100 \%$ had high and $45.8 \%$ had low values of $\beta$ hCG which was statistically significant $(\mathrm{p}<0.001)$, thereby concluding that raised $\beta$ hCG levels were significant in predicting pregnancy complication. This similar observation was made by Benn AP et al in which $26 \%$ had high and $9.9 \%$ had low values of $\beta$ hCG which was statistically significant $(\mathrm{p}<0.001)$ confirming that elevated maternal $\beta \mathrm{hCG}$ levels have association with adverse pregnancy outcome. ${ }^{4}$ However in the control group $75 \%$ had high levels of $\beta$ hCG and $26 \%$ had low levels of $\beta$ hCG which was statistically not significant $(\mathrm{p}=0.075)$. 
In the cases who developed PIH in study group, $82.4 \%$ cases had high levels of $\beta$ hCG and 6\% cases had low levels of $\beta$ hCG which was statistically significant $(p=<0.001)$ and was similar with the studies of Gonen $R$ et al $(p=<0.001)$, Desai P, Rao $S(p=<0.001)$ thereby concluding that in patients with PIH, early utero placental vascular changes may lead to reduced oxygen supply to the trophoblasts resulting in increased production of $\beta$ hCG. ${ }^{5,6}$ In the control group, cases who developed PIH, $0 \%$ cases had high of $\beta$ hCG and $10.9 \%$ cases had low values of $\beta$ hCG which were statistically not significant $(\mathrm{p}=1.000)$ similar with the study of Tanaka $\mathrm{M}$ et al and Johnson P $(\mathrm{p}=0.45)^{7,8}$

In the cases who developed IUGR in study group, $58.8 \%$ had high levels of $\beta$ hCG and $21.7 \%$ had low levels of $\beta$ hCG which was statistically significant $(\mathrm{p}=0.005)$ similar with the study of Gonen $\mathrm{R}$ et $\mathrm{al}(\mathrm{p}=<0.05)$ and Tanaka $\mathrm{M}$ et al $(\mathrm{p}=<0.001)$ suggesting that $\beta$ hCG can be a useful indicator for screening of IUGR. ${ }^{5,7}$ In the control group cases who developed IUGR, $25 \%$ had high levels of $\beta$ hCG and $13 \%$ had low levels which was not statistically significant $(\mathrm{p}=0.464)$ similar with the study of Wenstrom KID et al $(\mathrm{p}=0.21)$ and Yaron Y et al. ${ }^{9}$

The patients who developed preterm, still birth, abruption, PROM (premature rupture of membrane) were not having statistically significant relationship with $\beta$ hCG levels. Thereby concluding that raised $\beta$ hCG levels were not significant in predicting these complications.

\section{CONCLUSION}

Women with bad obstetric history and unexplained elevation of $\beta$ hCG during the second trimester are at an increased risk for Pregnancy Induced Hypertension and IUGR. Other complications like abortion, preterm, still birth abruption, PROM have no relation with $\beta$ hCG levels. Therefore we conclude that these women may require careful obstetric management to optimize outcome.

\section{ACKNOWLEDGEMENTS}

We, acknowledge our thanks to our patients and their friends who bestowed their trust on us and enabled us to show light to others in this regard.
Funding: No funding sources

Conflict of interest: None declared

Ethical approval: The study was approved by the Institutional Ethics Committee

\section{REFERENCES}

1. Yaron Y, Cherry M, Kramer RL, O'Brien JE, Hallak M, Johnson MP, et al. Second trimester maternal serum marker screening: maternal serum alpha fetoprotein, $\beta$ human chorionic gonadotropin, estriol and their various combinations as predictors of pregnancy outcome. Am J Obstet Gynecol. 1999;181(4):968-74.

2. Cunningham FG, Leveno KJ, Bloom SL, Hauth JC, Gilstrap LC, Wenstrom KD. Implantation embryogenesis and placental development: Williams Obstetrics 22nd ed. Mc Graw hill Medical Publishing Division; 2001:70-2.

3. Vaillant P, David E, Constant I, Athmani B, Devuldur G, Fievet $P$, et al. Validity in nulliparas of increased $\mathrm{p}$ Human chorionic gonadotropin at midterm for predicting pregnancy induced hypertension complicated with proteinuria and intrauterine growth retardation. Nephron. 1996;72:557-63.

4. Benn AP, Horne D, Briganti S, Rodis JF, Clive JM. Elevated second trimester maternal serum $\beta$ hCG alone or in combination with elevated alpha fetoprotein. Obstet Gynecol. 1996;87(2):217-22.

5. Gonen R, Perez R, David M, Dar H, Merksamer R, Sharf $M$. The association between unexplained second trimester serum $\beta$ hCG elevation and pregnancy complications. Obstet Gynecol. 1992;80(1):83-6.

6. Desai P, Rao S. Predictive value of raised midtrimester $\beta$ human chorionic gonadotropin in PIH. J Obstet and Gyn Ind. 2002;52(1):68-70.

7. Tanaka M, Natori M, Kohno H, Ishimoto $H$, Kobayashi T, Nozawa S. Fetal growth in patients with elevated maternal hCG levels. Obstet Gynecol. 1993;81(3):341-3.

8. Johnson P. Second trimester maternal serum $\beta$ human chorionic gonadotrophin and pregnancy outcome. Br J Obstet and Gynaecol. 1999;106:598600.

9. Wenstron KID, Owen J, Boots LR, Dubard MB. Elevated $2^{\text {nd }}$ trimester human gonadotropin levels in association with poor pregnancy outcome. Am J Obstet Gynecol. 1994;171(4):1038-41.

Cite this article as: Sharma $\mathrm{P}$, Maheshwari S,

Barala S. Correlation between second trimester beta human chorionic gonadotropin levels and pregnancy outcome in high risk group. Int J Reprod Contracept Obstet Gynecol 2016;5:2358-61. 